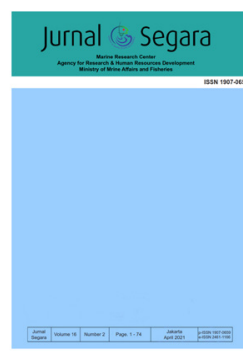

JURNAL SEGARA

http://ejournal-balitbang.kkp.go.id/index.php/segara

ISSN : 1907- 0659

e-ISSN : 2461-1166

Accreditation Number: 766/AU3/P2MI-LIPI/10/2016

\title{
MARINE-SEDIMENT CHARACTERISTICS AND THICKNESS OVER THE ERODED SAYUNG COAST, DEMAK, INDONESIA
}

\author{
Wisnu A. Gemilang ${ }^{1,2)}$, Ulung J. Wisha ${ }^{1)}$, Guntur A. Rahmawan'1), \& Koko Ondara1) \\ ${ }^{1)}$ Research Institute for Coastal Resource and Vulnerability, Ministry of Marine Affairs and Vulnerability, 25245 \\ Padang, Sumatera Barat, Indonesia \\ 2)Environmental Engineering Department, Sepuluh November Institute of Technology 60111 \\ Surabaya, Jawa Timur, Indonesia
}

Received: 17 June 2021; Revised: 14 April 2021; Accepted: 17 May 2021

\begin{abstract}
An over whelming erosion occurred in Sayung waters is related to sedimentary processes. That is why the deeper determination of sediment characteristics through direct survey and acoustic data retrieval is crucial. Several previous related studies had been conducted revealing the rate and model of sedimentation. This study aimed to describe the sedimentary processes according to its features and deposition. In this study, we conducted a grab-sampling, bathymetry surveys and also hydrodynamical model. Grain size analysis was employed to observe the characteristics of sediment and its deposition environment. At the same time, we applied dual-frequency bathymetry data for estimating sediment thickness which reflects the accumulation sediment over Sayung waters. We found that sediment texture varies from sand to clay, while coarse sediment fraction is dominant in the western part. Near the coastline area of Sayung waters reflecting the more potent transport mechanism in the deposition environment, proven by the less-accumulated sediment from 0-2.5 km from the coastline. In sea-ward regions, we observed the finer sediment fraction, showing that the low-transport mechanism takes place. The topographical alteration has intensively occurred at $2.5-3.2 \mathrm{~km}$ from the coastline. Tidal current has an essential role in inducing local transport whereby the speed varies ranging from $0-0.14 \mathrm{~m} / \mathrm{s}$, other than that, the more substantial current features have observed in Surodadi and Bedono coast moving perpendicularly toward the beach. In contrast, in the southern Sayung waters, the current profiles tend to be weak inducing higher sedimentation. Besides, the emergence of the sandbar has a role in reflecting sediment texture predomination in Sayung waters.
\end{abstract}

Keywords: Marine-sediment, sediment thickness, deposition environment, Sayung Waters.

Corresponding author:

Jl. Pasir Putih I Ancol Timur, Jakarta Utara 14430. Email: ulungjantama@gmail.com 


\section{INTRODUCTION}

Coastal zone is a mixing zone where the confluence between seawater and groundwater takes place. The nature of hydrology and fluvial systems formed the coastal area (Aylagas et al., 2017). The marine environment can be the most prone area to pollutions and coastal damages due to rapid urban development nowadays (Wei et al., 2009). Demak is a regency located on the northern coast of Java with an unstable soil structure where it was a bog area in the past (Yuwono et al., 2017). Moreover, Demak Regency is one of the regions undergoing tremendous erosion and coastline changes (Ismanto et al., 2017).

The loss of natural protection in the form of mangrove forests became one of the causes of coastline instability over the last decade (Tonneijck et al., 2015). Several regions within Demak Regency experiencing high erosion and sedimentation were Sayung, Bonang, and Wedung (Marfai et al., 2016). The eroded area was around 495.80 hectares (Ervita \& Marfai, 2017). The erosion events occurred affecting mangrove ecosystem damages, settlement and fisheries ponds, coastal resources threats, socialeconomic issues, and degradation of the environment (Nandi et al., 2016; Bouchahma \& Yan, 2014).

Several countries have used the sedimentary approach to enhance coastal management at specific spatial scales through the determination of sediment mobility and transport between each space (Thom et al., 2018). Within sediment deposits, it can reveal the environmental condition and grain size distribution. It was an essential objective of sedimentology (Mclaren \& Bowles, 1985). Knowledge regarding sediment texture characteristics is crucial in distinguishing any micro-environmental depositions (Ganesh et al., 2013).
Furthermore, it can determine water-transported materials, slopes, permeability, and structure stability, kinetic reaction, and heavy metal contamination (Costas et al., 2018). Through the acoustic-based hydrographical survey, it can determine the sediment accumulation. By analyzing the distribution of sediment thickness, we will gain the sediment bank's distribution and sediment deposition potential.

Several previous related-studies had been published. Sugianto et al. (2017) defined the potential of surface current in transporting cohesive sediment in Surodadi, while Gemilang et al. (2018) investigated mangrove effectivity-reduced abrasion and sedimentary rate in Sayung. Ismanto et al. (2017) developed a sediment transport model. Lastly, Gemilang et al. (2020) defined the rate of sedimentation using $210 \mathrm{~Pb}$ isotope analysis. On the other hand, the distribution of sediment thickness and grain size characteristics is still not well-identified. It is essential to figure the sediment behavior out. Thus, this study aims to describe the updated sediment characteristics and predict the thickness of sediment accumulation over the eroded Surodadi coast.

\section{METHODOLOGY}

\section{Study Site}

Generally, a young mountainous volcanic eruption and alluvium deposition, as well as an uncompacted loose coastal deposition, forms the northern land of Java. Quarter sediment lithology consists of tufa clay, clayey humus, sand, silt, and clay. Demak Regency geomorphologically is a lowland unfolded toward Semarang-Magelang arranged by alluvial deposition (Gemilang et al., 2020). Demak coastal area is a declivous intertidal coastline dominated by mud (cohesive sediment). This study focused on Surodadi

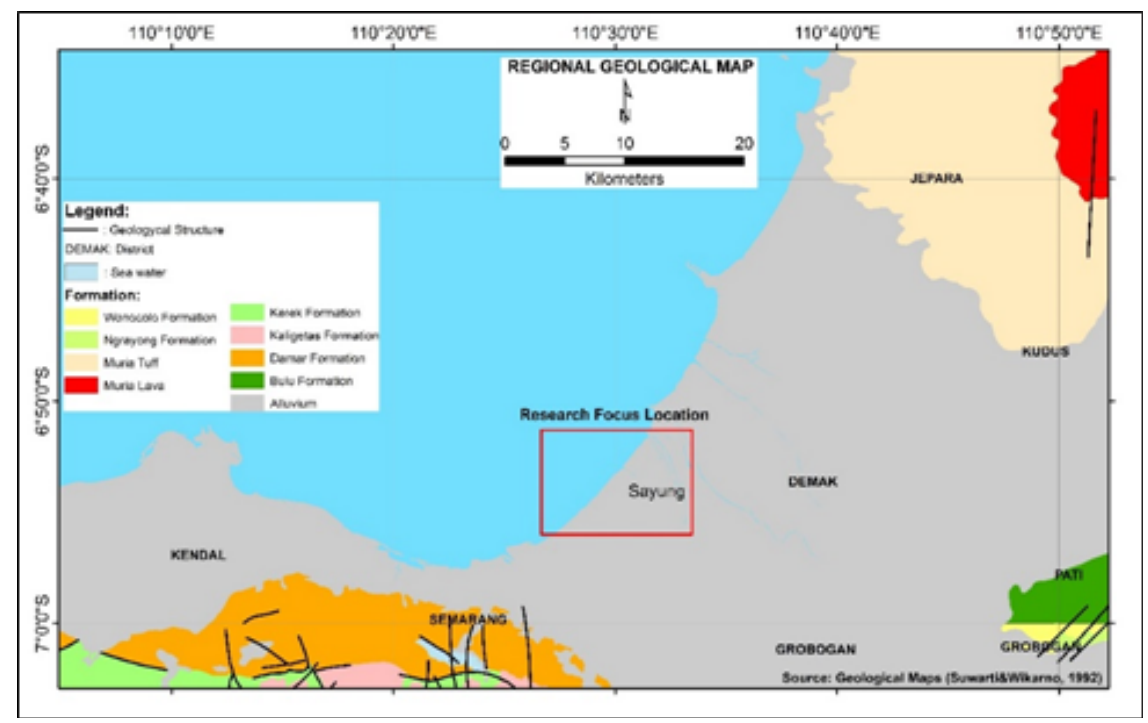

Figure 1. Regional geological map of Sayung. 
Village within Sayung sub-district, Demak which geographically positioned at $110^{\circ} 29^{\prime} 10^{\prime \prime}-110^{\circ} 31^{\prime} 40^{\prime \prime} \mathrm{E}$ and 6 50'50" - 6 52' 32" S (Figure 1). We chose Surodadi because this area was highly eroded and threatened by periodically tidal flooding.

\section{Data Acquisition}

Bottom sediment sampling was conducted during the first transitional season (on April $10^{\text {th }}-11^{\text {th }} 2018$ ) because the ocean-atmosphere interaction-induced wind is predicted getting stronger during transitional seasons. It is essential to research the two transitional monsoons. Still, due to a technical reason, we could not conduct the second survey. Thirty-one sampling points were scattered from east to west part of Surodadi coast. We considered tidal conditions to make sure that the term is in the spring tidal condition (Figure 2) whereby the tidal energy-induced current is quite forceful during this phase. A sampling-based coastal morphology division has done. We decided several significant points located in front of the sandbar, open sea, around estuaries, and in the surrounding hybridengineering structures. The depth of sediment sampling was around 1.5-3.5 meter beneath the surface. Also, we used the Ekman Grab Sampler tools model 196B15.

To determine the tidal current pattern during sampling time, we simulated the flow model hydrodynamic with a flexible mesh. The model developed was based on the discretization of momentum and continuity equation. We considered two boundaries that are representing tidal conditions in the west and north of the modelled area. Moreover, we used bathymetry data gained from field survey, tidal forecast, and on-screen digited shoreline as model input. The model result will be mapped just for the spring high tidal condition as the sediment sampling has done. Moreover, we picked three points out to compare the transport mechanism within the modelled area.

\section{Sediment Data Analysis}

Samples were analyzed in the laboratory to determine the sediment type and grain size. The grain size was determined using the granulometry method (Hubbard \& Pocock, 1972) (Hsieh, 1995). The separation of grain sizes was filtered according to sizes of $>2$; $1.4 ; 1 ; 0.5 ; 0.250 ; 0.150 ; 0.090 ; 0.063$; and $<0.063 \mathrm{~mm}$. This analysis generally was done to decide the resistance level of grains toward exogenic processes. To exemplify, the processes of weathering, erosion, and abrasion, where sediments will be transported from its provenance and determined its deposition process (Yasin et al., 2016). However, we used the Wentworth scale to classify the grain size. The Wentworth scale is a standard system used to figure the particle grain size of clastic sediment out (Wenworth, 1922). This scale is feasible to analyze the sediment grain size precisely up to $0.0001 \mathrm{~mm}$ (clay sediment). We used this scale because the sediment grain size in the study area is categorized into clasticsized sediment.

Sediment type determination had done according to the ternary triangle diagram classification established by Shepard in 1954 (Dyer, 1986). The statistical approach applied to sediment grain size groups was employed to interpret sediment distribution, transport mechanism, and sediment deposition. Statistical parameters used in this study were sortation, skewness, kurtosis classified based on Folk \& Ward (1957).

\section{Sediment Thickness Analysis Based on Bathymetry Data}

From a bathymetry survey, we gained water depth variability in the form of high frequency (HF) and low frequency (LF) data. Those data were corrected using tidal data analyzed by employing the admiralty method to obtain its harmonic constituents (Rahmawan et al., 2017). The reference for determining the real depth of seawaters is chart datum which is a reference field beneath the surface water fixed to define the number of depths within the bathymetry map. Chart datum can be determined using the following formula:

$$
C_{D}=S_{o}-Z_{o}
$$

Where,

$C_{D}=$ Chart Datum / Ebb surface on map

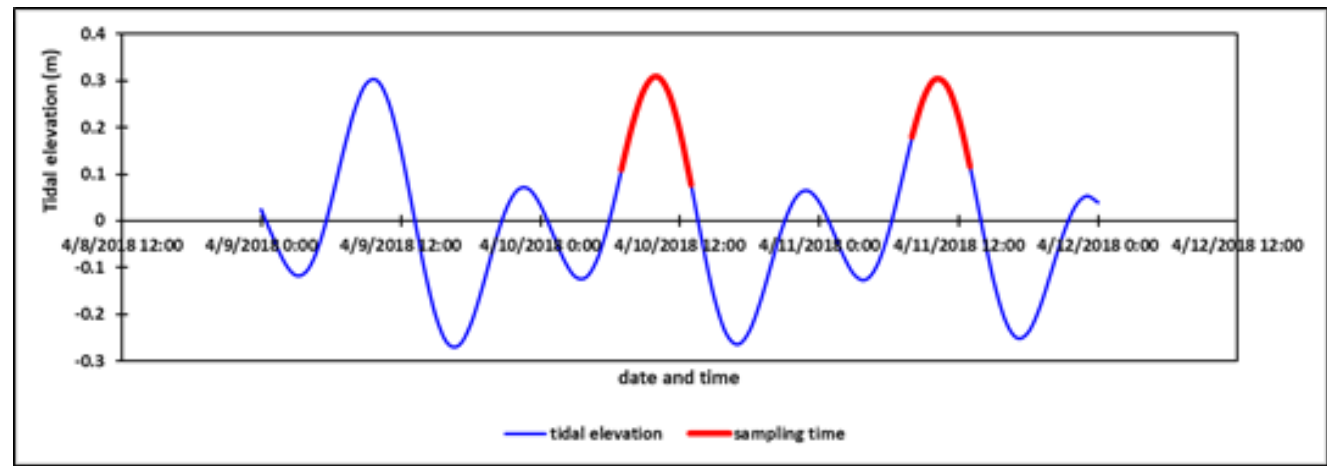

Figure 2. Tidal condition during sediment sampling time in Sayung waters. 
$\mathrm{S}_{\mathrm{o}}=$ Middle level above the zero point of measurement

$$
Z_{0}=\text { The distance of ebb surface }
$$

The real depth values were then processed using interpolation spatial analysis to gain the distribution value of channel 1 (HF) and channel $2(\mathrm{LF})$. The acoustic signals between HF and LF worked together at the same time during the field survey without biasing the function and the measured data (Rahmawan et al., 2019). After the interpolation stage had done, we used a grid method with $10 \times 10$ meters transects to estimate the sediment volume using frustum formula (Rauf \& Winarno, 2017). To map the thickness distribution of sediment, we used the deviation of the two-channel volume (Rahmawan et al., 2019).

\section{RESULTS AND DISCUSSION}

\section{Statistical Analysis of Sediment}

Sediment texture characteristics such as mean $(\mathrm{Mz})$, standard deviation ( $\sigma 1)$, skewness (Ski), and kurtosis (KG) generally are used to reconstruct the depositional environment of sediment (Amaral \& Pryor, 1977). The correlation between grain size and the transport mechanism of sediment has been used thoroughly by modern studies to classify the depositional environment (Malvarez et al., 2001).

According to Mean (Mz) parameter, it indicates that the sediment in the study area categorizes in the very fine sand group settled in the deficient energy environment. The values of phi gained from sediment samples vary ranging from $3.27-5 \Phi$, with the average of $4.23 \Phi$ (Figure $3 A$ ). Generally, all of the samples categorized into very fine sand because the mean parameter value is more than $3 \Phi$. The mean parameter of sediment is determined by sediment provenance, the transporting media, and the energy in the depositional environment (Kumar et al., 2010).

Skewness (Ski) asymmetrically measures the distribution frequency of sediment. The value of skewness in the study area ranges from 0.26 up to -0.70 , with an average of -0.17 (Figure $3 \mathrm{~B}$ ). According to the sample symmetry, it is categorized into fineskewed (12.09\%) up to coarse-skewed (54.85\%). The rest of the samples classified into symmetrical skewed with around $32.26 \%$. Negative value predomination of sediment skewness with about $58.06 \%$ indicates that the sediment deposition occurred in an intense energy environment and vice versa for positive skewness (Rajasekhara et al., 2008).

Figure $3 \mathrm{C}$ shows the volume of standard deviation $(\sigma 1)$ of sediment sortation and the fluctuation of kinetic energy. It indicates that the difference in kinetic energy associated with sediment deposition mode (Ganesh et al., 2013). However, the variation of sortation value illustrates the difference in turbulence beneath the surface and the variability of current speed during the deposition processes (Venkatramanan, 2011). The sortation value of study area ranges from $0.68 \Phi-1.74 \Phi$ with the average of $0.91 \Phi$. Generally, sortation characteristic in the study area categorized into moderately sorted $(74.19 \%)$. The regular addition of sediment materials with fine/coarse size and various proportion has a role in sortation.

Figure 3D shows the kurtosis value of sediment in the study area. It illustrates the ratio between sortation graphs ranging from 0.69-1.59 with an average of 1.05. Generally, we categorized the kurtosis value into mesokurtic with around $48.39 \%$. The rest samples

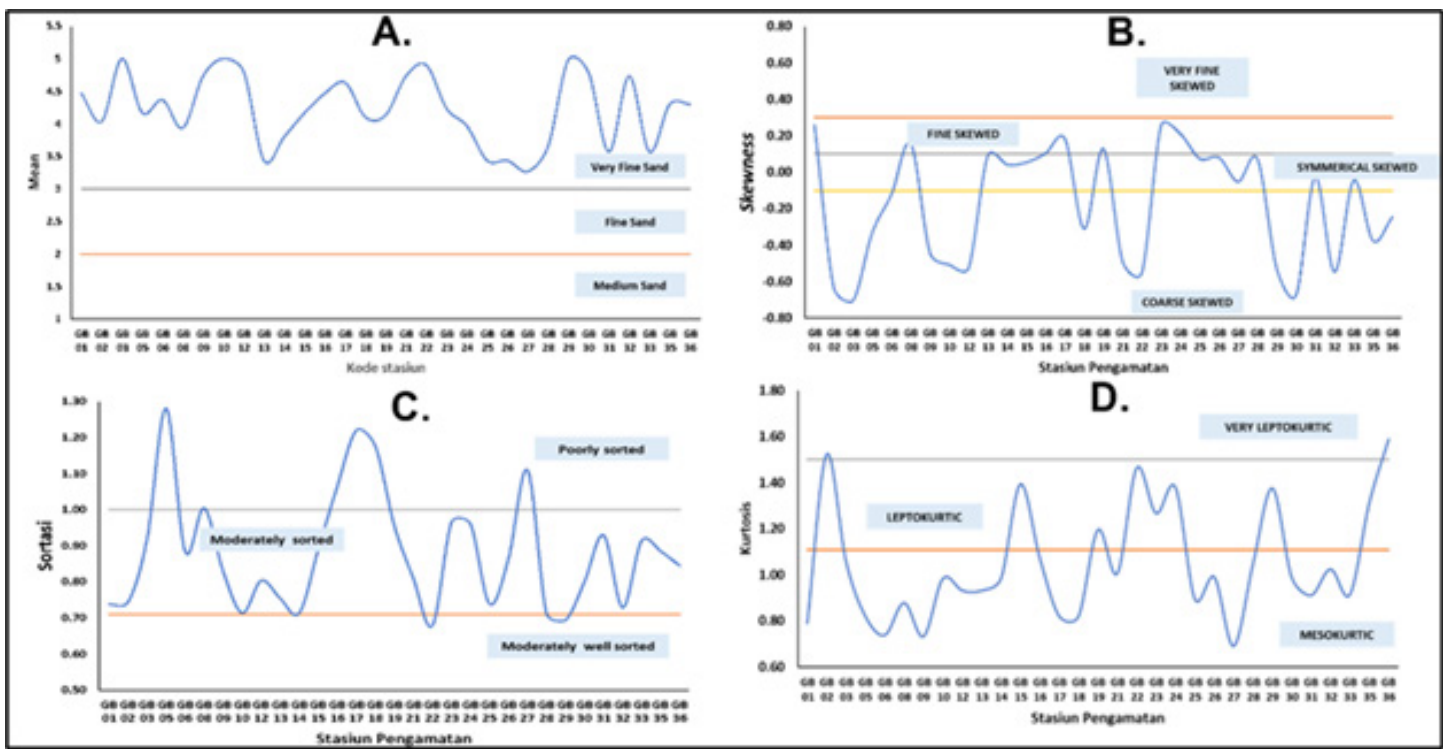

Figure 3. Statistical analysis of sediment grain size in Sayung waters; A. Mean; B. Skewness; C. Sortation; D. Kurtosis. 
show leptokurtic and platykurtic categories. It indicates that parts of sediment have been reached a sorted phase in the different places with a more robust energy environment (Deepthi et al., 2018). Kurtosis variation is most likely to reflect the characteristics of the current flow during the transportation process.

\section{Sediment type in Sayung Waters}

The grain size of bottom sediment varies at each station (Figure 4). Figure 5 shows the result of grain size analysis based on the triangle Shepard diagram 1954, thereby quickly interpreting the sediment type according to its textures. Overall, there are five sediment textures identified in the study area, including sand, silty sand, sandy silt, clayey sand, and clayey silt. However, in general, sediment texture in Sayung waters is predominated by sand and sandy silt sediments. This result is quite different from the previous study by Pranoto et al. (2016). It discovered that the bottom sediment type is silt and clayey silt, whereby silt sediment predominates in Sayung waters. This issue proves that there are several changes to the deposited sediment type throughout 2015-2018. However, different observation sites may also result in different kind of analyzed sediment.

Several sandbar morphologies arrange the Surodadi coastal area in front of mangrove forests. This condition affects sandy silt sediment predomination in the southwestern part of Sayung District. The presence of elongated sandbars influences on local sediment texture. In the eastern part, the sediment texture is slightly different. The influences from estuaries and rivers occur, resulting in the mixed and clayey sand sediment domination (mixed zone) (Figure 6).
Differences in grain size reflect the sediment provenance. The more toward the coast and mangrove forest, the finer, the sediment exists and vice versa. This condition indicates that sea-sourced sediment was experiencing transportation until it reaches the deposition environment. Furthermore, grain size, which tends to be coarse, suggests that the erosion of sandbar triggered by ocean waves and eventually deposited in front of Sayung waters. While the finer sediment predomination in the coastal area is a result of a regular monsoon cycle in the Java Sea, we conducted this study during the first transitional season. The wind tended to be weak, and the direction was arbitrarily erratic (Siregar et al., 2017). Due to the weak wind-driven current profile, the finer size of sediment tends to move costal-ward.

On the other hand, according to (Chen et al., 2015), the river flow entering coastal area undergoes retardation, resulting in a declined transport mechanism. The materials carried by the flow will tend to settle in the estuary. Furthermore, river-sourced sediments are commonly fine grain, such as silt sediment, which is easily moved by tidal currents. In the estuarine area where the tidal current influence is predominant, the transport mechanism will also be arbitrarily erratic (Hoekstra et al., 2003).

The higher surface elevation of river flow causes the tendency of fine-grain sediments in Sayung waters during the low tidal conditions, so that river settling is dominant. Unlike ebb tides, during the high tidal condition, sea surface elevation is higher than river elevation, resulting in the amalgamation between fine and coarse sediments. Based on the survey result,

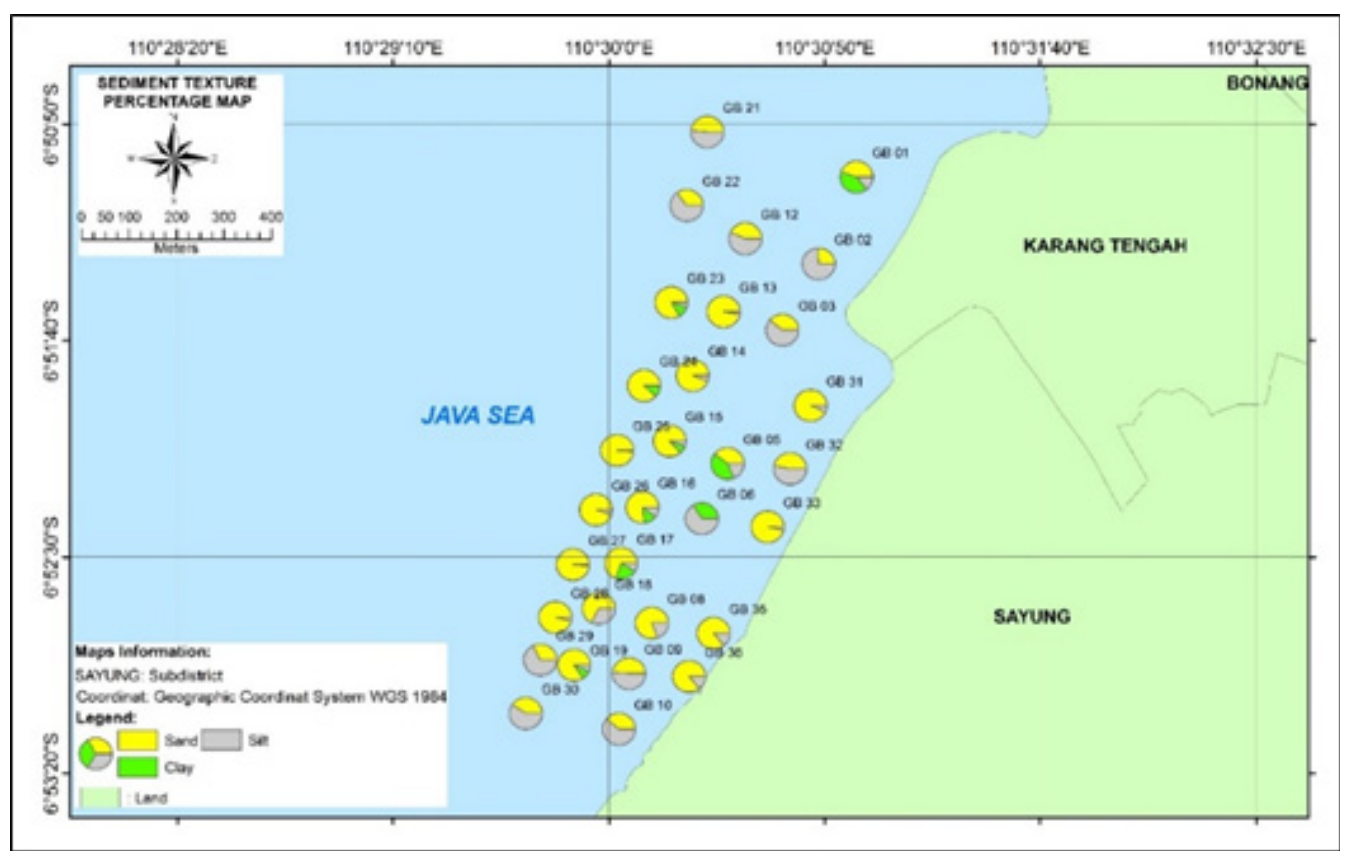

Figure 4. Sediment texture percentagewise in Sayung waters. 
during the high tidal conditions, the sediment in the estuary is predominated by sandy silt up to sand sediments. Whereas, other areas that are far from estuaries, the sediment deposition is represented by the finer grain sediment such as silt-silty sand. In contrast, in the surrounding sandbar areas, the tendency of coarser sediment is identified (sand-silty sand) (Figure 6). According to the sediment texture distribution in Figure 6 , in the northern and southern Sayung waters, sediment type is defined by river sediment intake. The dominant sea current flow from north and south induces sediment mixing behind the sand bar. The coarser sediment in front of the sandbar shows that the stronger current flows perpendicularly toward the coastline.

\section{Sediment Thickness Distribution and Topographical Changes}

The differences and changes of water depth profiles are shown in Figure 7, where the green line represents the erratically sloping contours formation. In contrast, the red line represents uniform sloping contours formation. These prove that there is a variation in water depth. In the area near the coastline, the difference of water depth between channels 1 and 2 is not too significant, which is shown by coincided redgreen lines. Otherwise, increasingly towards the open sea, the more dissever those two lines. It shows that HF and LF channels can determine a plethora of different depths. Those differences reflect the variability of sediment thickness in Sayung waters where the more

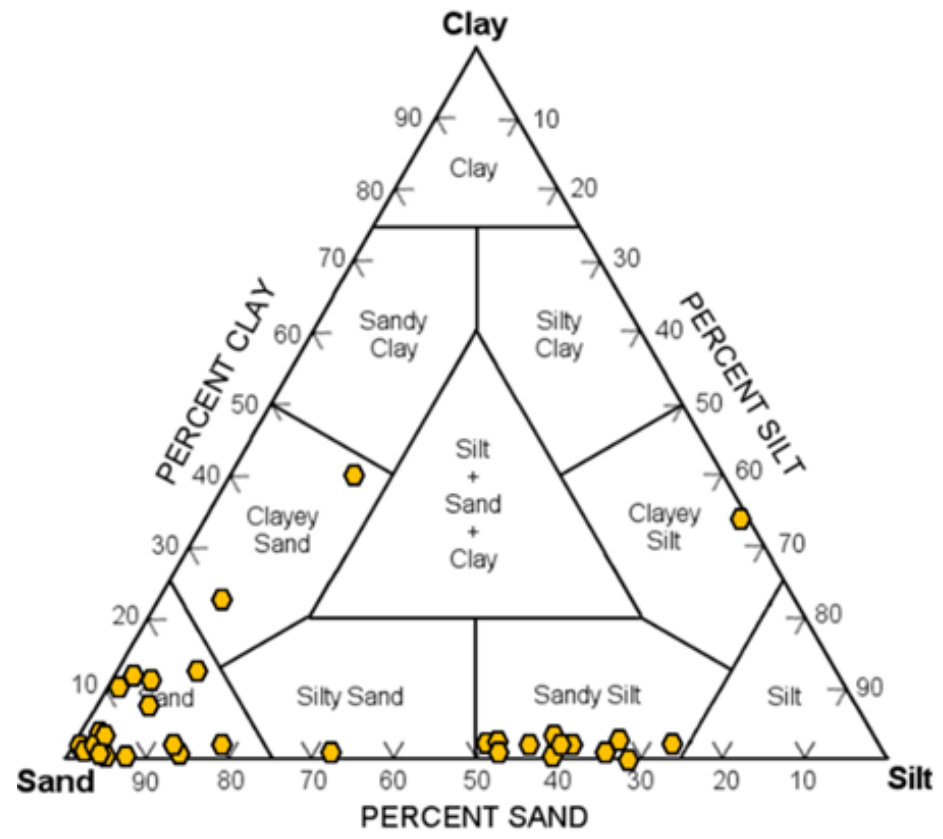

Figure 5. Percentage and types of sediment in Sayung waters plotted in the triangle Shepard diagram 1954.

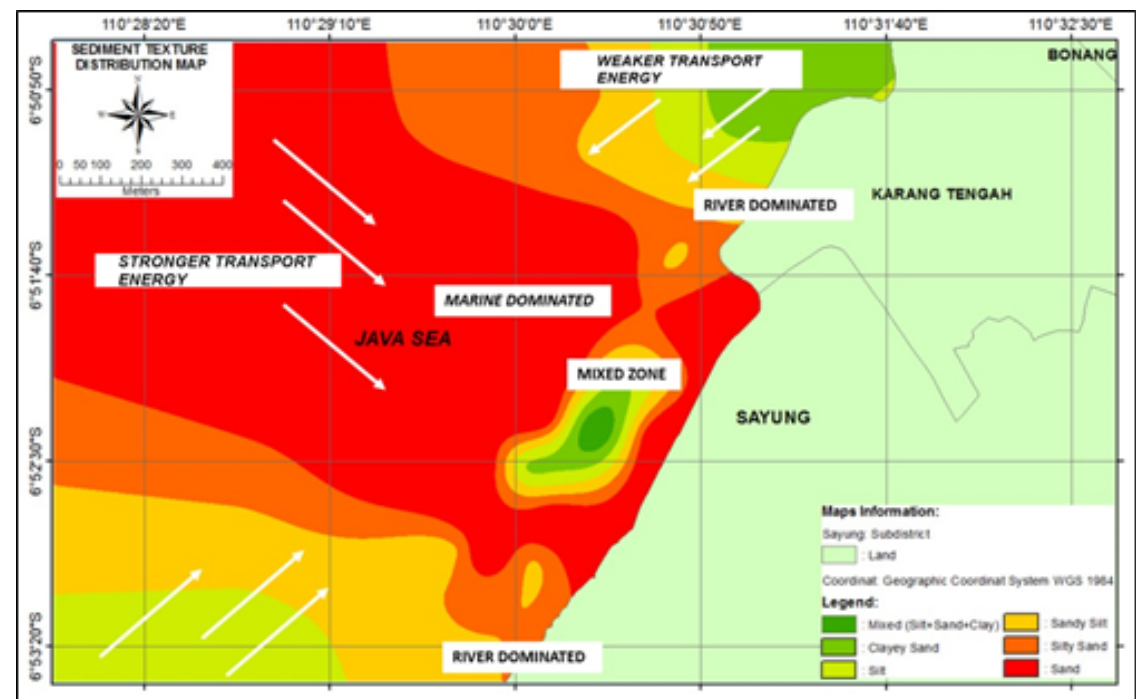

Figure 6. The map of sediment texture distribution in Sayung waters. 


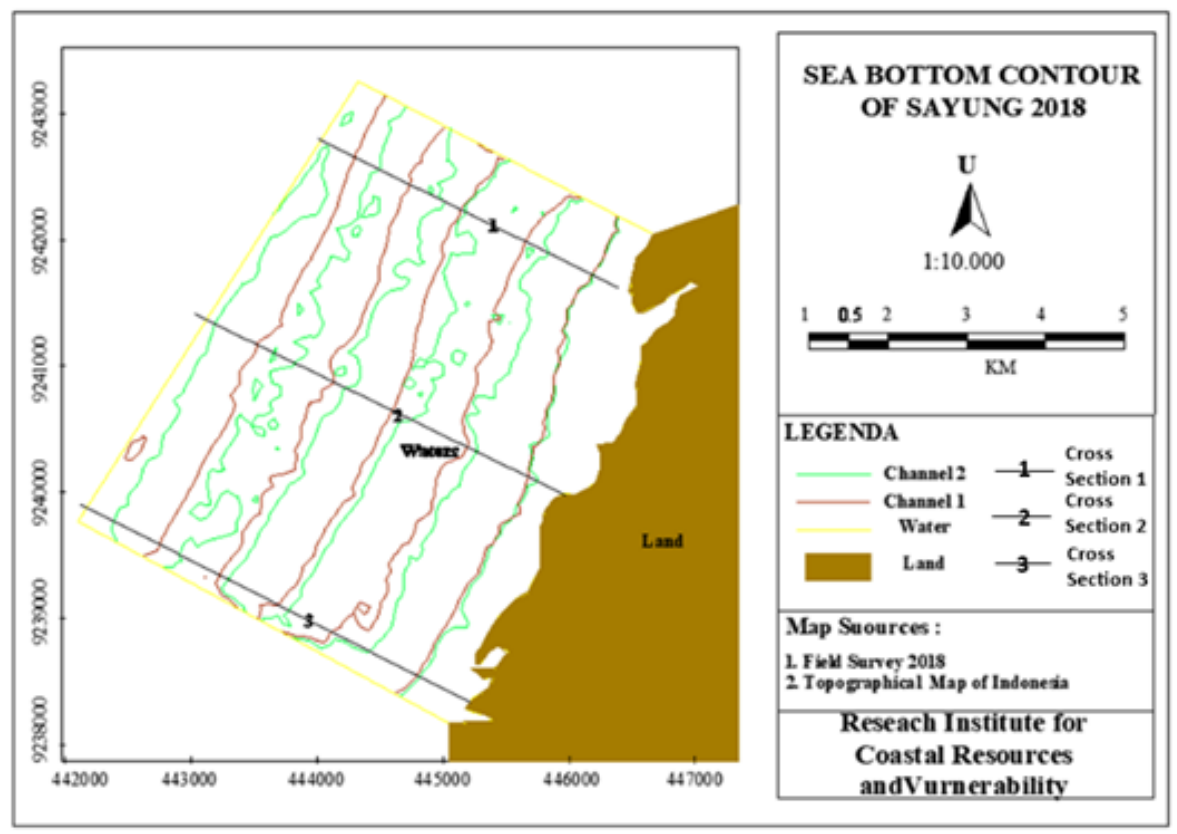

Figure 7. A contour map and bathymetry cross-section in Sayung waters.

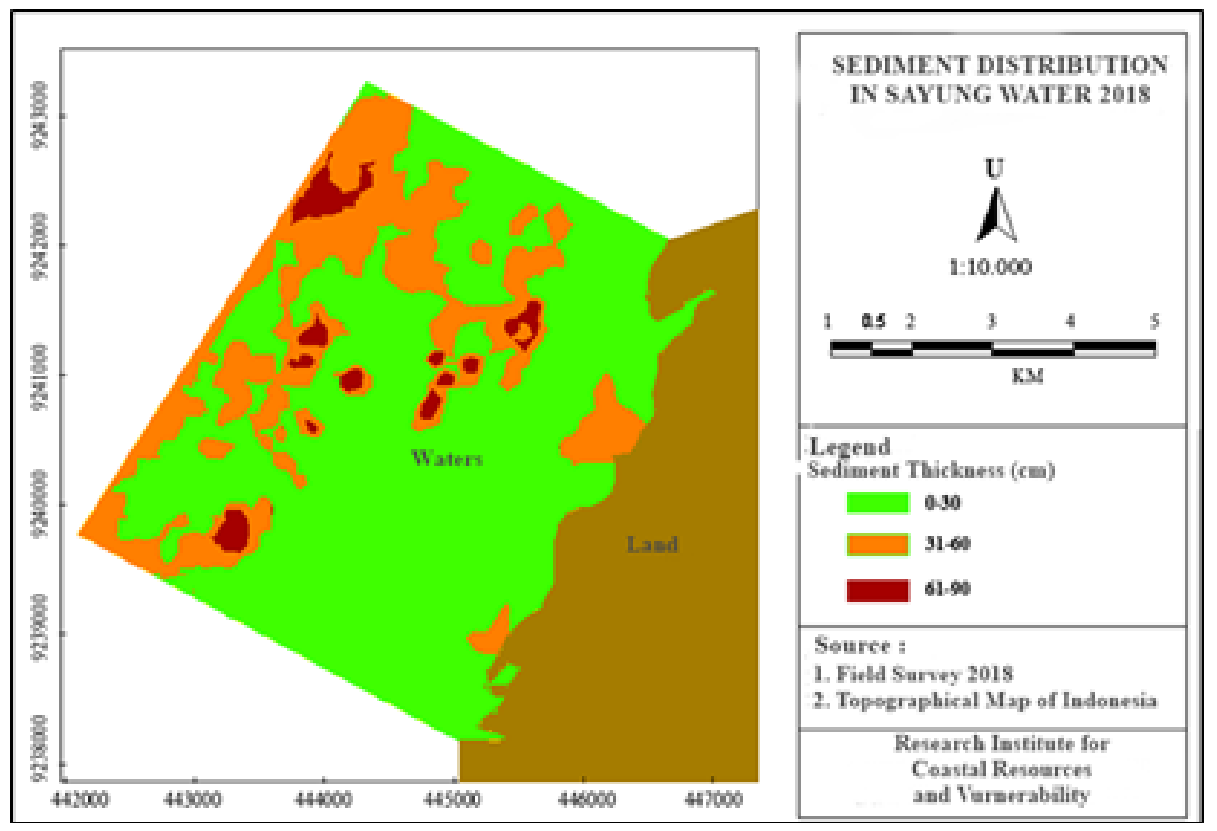

Figure 8. Sediment thickness distribution in Sayung waters.

sea-ward, the thicker sediment accumulation identified.

Regarding the distribution of sediment thickness (Figure 8), overall, the sediment thickness in the study area ranges from $0-30 \mathrm{~cm}$. The scattering is around $74.83 \%$. The total area of distribution was around 9.81 $\mathrm{m}^{2}$, which is scattered prevalently from the coastline up to $1.5 \mathrm{~km}$ sea-ward. The sediment thickness of $31-60$ $\mathrm{cm}$ is scattered around $15 \%\left(2.10 \mathrm{~m}^{2}\right)$, located from 1.5 up to $3 \mathrm{~km}$ sea-ward with the uneven distribution at certain spots in coastal areas. While the sediment thickness ranging from $61-90 \mathrm{~cm}$ is randomly identified between 1.5-3 km seaward with an area percentage of $9.91 \%\left(1.31 \mathrm{~m}^{2}\right)$. Also, total sediment accumulation volume in Sayung waters reached 3.403.444 $\mathrm{m}^{3}$. Thus, we can calculate that the average of sediment thickness in Sayung waters is around $26 \mathrm{~cm}$.

Graphs in Figure 9 show the cross-section lines informed in Figure 7, which represents the north (profile 1 ), central (profile 2), and south (profile 3) waters of Sayung. Overall, except for cross-section profile three, the topographical differences in cross-section profiles 1 and 2 show an erratic pattern. The bathymetry profile shown in profile one ranges from -0.5 up to -6.5 meters. The sediment accumulation is significantly 
observed approximately $1.5 \mathrm{~km}$ from the coastline with a thickness of around 1.5 meters. In comparison, the other identifications show between a distance of 2-3.2 $\mathrm{km}$, the thickness of sediment is around 0.65 meters. In profile 2, we can see that the depth ranges from -0.6 up to -6.6 meters. Between a distance of $0-3.2$ $\mathrm{km}$ from the coastline, the significant topographical changes are $2 \mathrm{~km}$ from the coastline. The sediment thickness identified is around 1.2 meters. In contrast, we observed sediment accumulations areas at 1.3-1.5 $\mathrm{km}$ and 2.2-2.5 km, with around 0.8 meters thickness, respectively.

The rest cross-section is profiling three, which between HF and LF channels show almost the same bed morphology pattern. It means that there is no significant sediment accumulation identified along this cross-section line. We observed a slight sedimentary tendency at a distance of 2-3.1 km, whereby the sediment thickness is approximately 0.2 meters.

\section{Sediment Deposition Mechanisms}

Sediment deposition processes in Sayung waters can be predicted based on granulometry and statistical analysis. We analyzed the grain size characteristics to interpret sediment distribution, transport mechanism, and sediment deposition in an area (Korwa et al., 2013). Generally, the sediment type in the study area is predominated by fine to coarse grains (silt - sand). This condition indicates that currents have a role in controlling sedimentary processes. Coarse sediments reflect the strong currents influence and vice versa. This statement is espoused by (Hidayat \& Rozamuri, 2016) that grain size is an indication of currents and waves strengths that work in the deposition environment.

On the other hand, sortation values indicate the deposition type, the characteristic of settling-currents, and the settling duration (Solahuddin et al., 2006). Sediments scattered and deposited in the study area show that the slightly short settling duration. It is proven by the high value of sortation (poorly sorted moderately sorted), indicating the lower-uniform grain size.

Grain-sized sediment in the study area is categorized into coarse-fine fractions indicating that the dominant transport mechanism is bed-load and

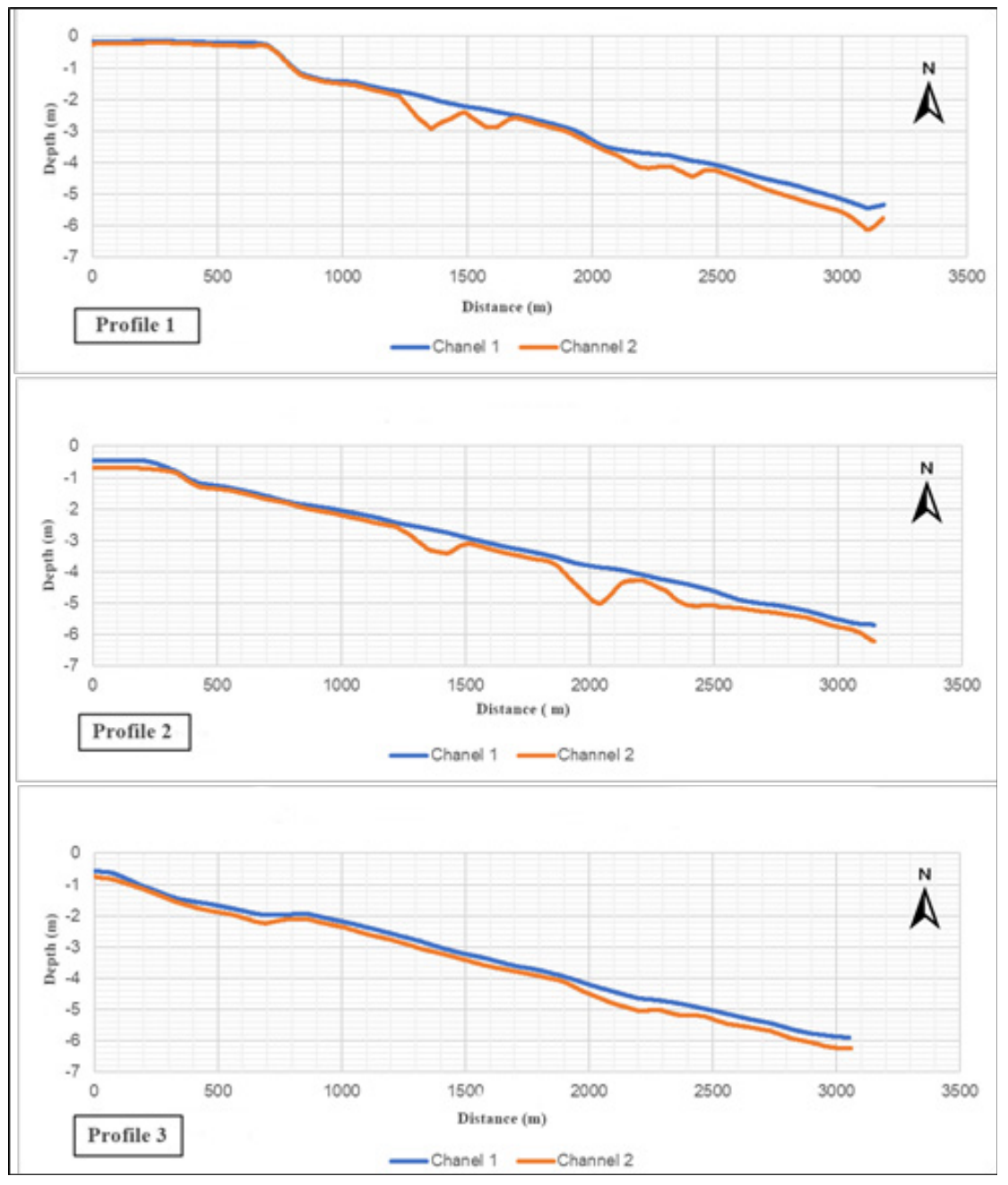

Figure 9. Cross-section graphs of HF-LF result's comparison. 


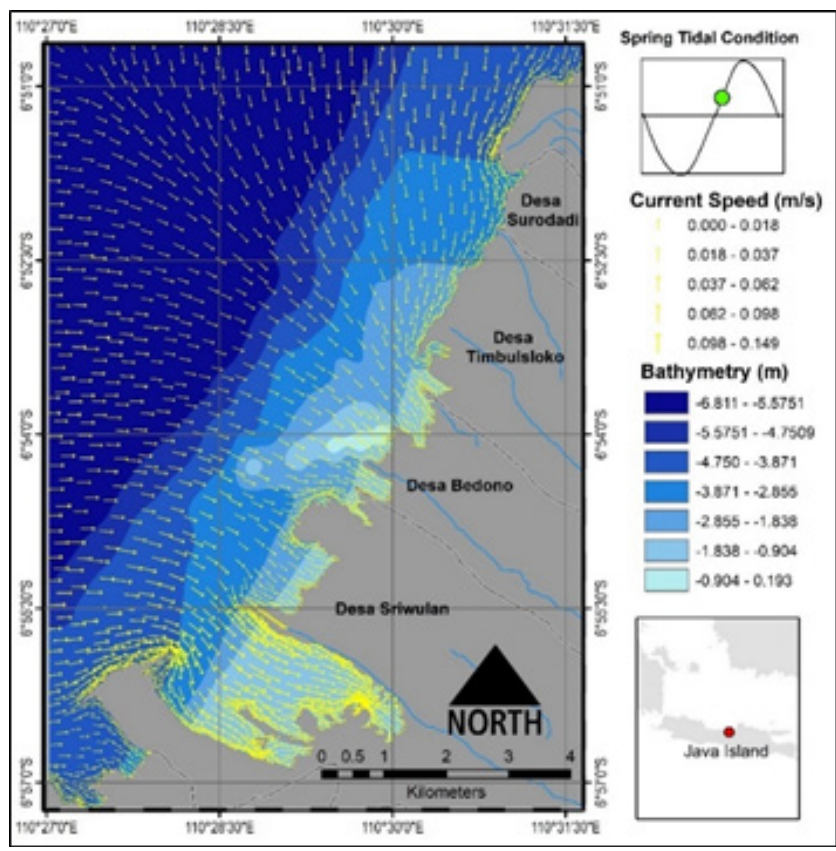

Figure 10. Tidal current pattern during the high spring tidal condition.

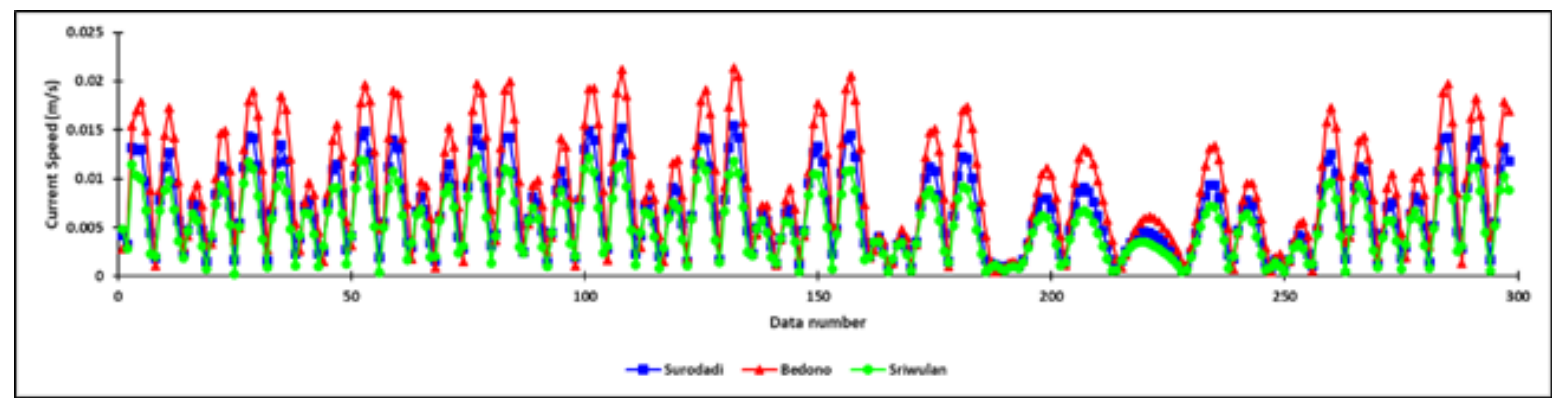

Figure 11. Current speed comparison between three significant locations in Sayung waters.

suspended-load. Bed-load transport will be experienced by the coarser fraction in the form of rolling, sliding, creeping, and saltation. However, the finer fraction undergoes transportation in the form of suspendedload carried sufficiently far within the stream, eventually settling in the deposition environment (Nugroho \& Basit, 2014). The sedimentary mechanism in Sayung waters depends on estuaries, where tidal current-driven transport is predominant. That is why in the estuarine areas, the mixing sediment fractions take place.

The current profile during the sampling time is shown in Figure 10. Overall, during the high spring tidal condition, the current speed ranged from $0-0.14 \mathrm{~m} / \mathrm{s}$. The southerly and northerly tidal current flowed along the coast of Sayung. In contrast, stronger current moved perpendicularly coastal-ward in Bendono waters. That is why the most eroded coastline is Bedono (Abiyoga et al., 2018). This pattern confirms the sediment texture distribution shown in Figure 6. The longshore current distributes river-sourced sediments from northern and southern Sayung waters in the opposite direction. The current deformations generated by the emergence of sandbar tend to erode the coastline behind, resulting in the higher suspended sediment concentration espoused by river intake (Wisha et al., 2017).

Figure 11 shows the comparison of current speed fluctuation between the three different locations, representing the north, central, and south part of Sayung waters as we cross-sectioned in Figure 7. We observed that overall, the current magnitude follows the tidal elevation changes. In other words, tidal current is predominant in Sayung waters. During the field survey, the current speed ranges from $0-0.15 \mathrm{~m} / \mathrm{s}$, $0-0.2 \mathrm{~m} / \mathrm{s}$, and $0-0.12 \mathrm{~m} / \mathrm{s}$ in the northern, central, and southern parts of Sayung waters, respectively. This comparison also espouses the result of morphological changes shown in Figure 9, whereby we observed the relatively altered sediment accumulation in the northern and central of Sayung waters (profile 1 and 2). The more substantial current magnitude in those locations induces an erratic influence on sedimentation. However, the finer sediment tends to settle during low tidal conditions, which results in the significant sediment thickness. While, the weak transport mechanism in the southern of Sayung waters, proves that in this area, the bed sediment is not intensively suspense following the 
low alteration of sediment thickness.

Regarding the sediment deposition, in the eastern part of Sayung, fine sediment fraction (mixedclayey sand) is relatively settled. In contrast, in the western part, coarse sediment type is predominantly categorized from sand to silty sand. However, fine sediment faction is scattered sea-ward, proven by the variability of sediment thickness sea-ward that is arbitrarily erratic. It shows that transported fine sediment will accumulate sea-ward where the scour and sediment resuspension probably decreased (Rahmawan et al., 2019). Moreover, the emergence of the sandbar in front of estuaries has a role in evoking the variation of sediment fraction in Sayung waters (Gemilang et al., 2018). Sediment transport in the tidally estuarine area of Sayung depends on the fluctuation of tidal phases. During high tidal conditions, wind-driven currents and tidal currents-induced longshore transport potentially evoke erosion in the coastal, estuarine, and surrounding sandbar areas (Sugianto et al., 2017). The contrast sedimentary environment between the east and west part of Sayung waters indicates that the erratic force of the tidal current and different sediment provenance occurs.

On the other hand, the existence of mangrove forests in the study area has a role in trapping sediment. The waves and currents propagation can significantly decline while inundating mangrove ecosystems, resulting in accumulated sediment behind the roots (Gemilang et al., 2018). However, the different abundance of mangrove populations will yield different sedimentary levels (Habib et al., 2017). Moreover, less-accumulated sediments near the coast show the higher active transport mechanism in the coastal area, which is proven by the low thickness value identified coast-ward. Continental drift occurred in Sayung waters is induced by several factors, such as the unstable deposition processes. It is most likely to reflect the character of grain size sediment.

\section{CONCLUSION}

Sediment fraction in Sayung waters varies whereby it is scattered differently in the eastern and western parts. According to its statistical analysis, the sediment type categorized from fine-coarse fractions, which reflect the deposition environment. A more potent transport mechanism along the coastline area inducing coarse sediment accumulation resulted from weathering is dominant. In contrast, the finer sediment fraction is dominant in the sea-ward area, which reflects the lower transport mechanism. The tidal current flow controls the sedimentation over the Sayung coast. The sufficiently strong currents from north and seaward induce an erratic influence on sedimentation. Also, sediment accumulation is observed higher in the sea- ward area, where the significant sediment thickness located. It will evoke bed contour changes if the transport mechanism tends to be erratic due to the existence of sandbar in front of estuarine and coastal areas.

Due to technical reasons, this study is only applied for the first transitional season period in 2018. It is expected to gain different results for other monsoon conditions. We do recommend for further studies to complete and compare the marine-sediment characteristics and its thickness in the different monsoon phases so that we can figure the sedimentary behavior out in Sayung Region as a basis for further mitigation efforts.

\section{ACKOWLEDGEMENTS}

Acknowledgment and gratitude are given to Research Institute for Coastal Resources and Vulnerability (RICRV) research funding in Sayung, Demak in 2016, and 2018, and to those who helped in the completion of this works. The main contributors of this article are Wisnu Arya Gemilang and Ulung Jantama Wisha.

\section{REFFERENCE}

Abiyoga, R., Suryanti, S., \& Muskananfola, M. (2018). Development strategy of mangrove conservation in Bedono Village, Demak Regency. Management of Aquatic Resources Journal, 6(3), 293-301.

Amaral, E. J., \& Pryor, W. A. (1977). Depositional environment of the St. Peter Sandstone deduced by textural analysis. Journal of Sedimentary Research, 47(1), 32-52. https://doi.org/https:// doi.org/10.1306/212F70EA-2B24-11D7 8648000102C1865D

Aylagas, E., Borja, A., Tangherlini, M., Dell'Anno, A., Corinaldesi, C., Michell, C. T., ... RodriguezEzpeleta, N. (2017). A bacterial community-based index to assess the ecological status of estuarine and coastal environments. Marine Pollution Bulletin, 114(2), 679-688. https://doi.org/https:// doi.org/10.1016/j.marpolbul.2016.10.050

Bouchahma, M., \& Yan, W. (2014). Monitoring shoreline change on Djerba Island using GIS and multi-temporal satellite data. Arabian Journal of Geosciences, 7(9), 3705-3713.

Chen, J.L., Hsu, T.J., Shi, F., Raubenheimer, B., \& Elgar, S. (2015). Hydrodynamic and sediment transport modeling of New River Inlet (NC) under the interaction of tides and waves. Journal of Geophysical Research: Oceans, 120(6), 4028- 
4047. https://doi.org/10.1002/2014JC010425

Costas, S., Ramires, M., Sousa, L.B. De, Mendes, I., \& Ferreira, O. (2018). Surficial sediment texture database for the south-western Iberian Atlantic margin. Earth System Science Data, 10(2), 1185-1195.

Deepthi, K., Natesan, U., Muthulakshmi, A.L., Ferrer, V.A., Narasimhan, S.V., \& Venugopalan, V.P. (2018). Grain Size Analysis for Elucidation of Depositional Environment of Kalpakkam, India. Environmental Processes, 5(1), 183-199.

Dyer, K.R. (1986). Coastal and estuarine sediment dynamics. Chichester: John Wiley and Sons.

Ervita, K., \& Marfai, M.A. (2017). Shoreline Change Analysis in Demak, Indonesia. Journal of Environmental Protection, 8(8), 940-955. https:// doi.org/10.4236/jep.2017.88059

Ganesh, B., Naidu, A.G.S.S., Rao, M.J., \& Karudu, T.K. (2013). Studies on textural characteristics of sediments from Gosthani River Estuary Bheemunipatnam , A . P ., East Coast of India. J.Indo.Geophys. Union, 17(2), 139-151.

Gemilang, W.A., Wisha, U.J., Ondara, K., \& Dhiauddin, R. (2018). Hybrid engineering effectivity evaluation according to the changes in mangrove area and sedimentary rate in the eroded area of Sayung Regency, Demak, Central Java. IOP Conference Series: Earth and Environmental Science. https:// doi.org/10.1088/1755-1315/216/1/012040

Gemilang, W.A., Wisha, U.J., Solihuddin, T., Arman, A., \& Ondara, K. (2020). Sediment Accumulation Rate in Sayung Coast, Demak, Central Java Using Unsupported. Atom Indonesia, 46(1), 25-32. https://doi.org/https://doi.org/10.17146/ aij.2020.935

Habib, A., Suripin, S., \& Sugianto, D.N. (2017). Simulation of Coastal Erosion Model to Support Disaster Mitigation in Coastal Sayung, Demak District. International Conference on Coastal and Delta Areas, 285-293.

Hidayat, R., \& Rozamuri, M.F. (2016). Comparison of Grain-Size Profile and Depositional Process in Mandeh and Nyalo Bar, Mandeh Bay, West Sumatera, Indonesia. Journal of Applied Geology. 1(1), 36-42. https://doi.org/10.22146/jag.26958

Hoekstra, P., Lindeboom, H., Bak, R., Bergh, G. van den, Tiwi, D. A., Douven, W., ... Weering, T. van. (2003). Teluk Banten Research Programme: an integrated coastal zone management Study. In W. J. M. Levelt (Ed.), Scientific Programme IndonesiaNetherlands (pp. 59-70). Bandung: Koninklijke Nederlandse Akademie van Wetenschappen.

Hsieh, H.L. (1995). Spatial and temporal patterns of polychaete communities in a subtropical mangrove swamp: influences of sediment and microhabitat. Marine Ecology Progress Series, 127, 157-167. https://doi.org/10.3354/meps127157

Hubbard, J.A.E.B., \& Pocock, Y. P. (1972). Sediment rejection by recent scleractinian corals: a key to palaeo-environmental reconstruction. Geologische Rundschau, 61(2), 598-626.

Ismanto, A., Zainuri, M., Hutabarat, S., Sugianto, D. N., Widada, S., \& Wirasatriya, A. (2017). Sediment Transport Model in Sayung District, Demak. IOP Conference Series: Earth and Environmental Science, 55(1). https://doi.org/10.1088/1755$1315 / 55 / 1 / 012007$

Korwa, J.I.S., Opa, E.T., \& Djamaludin, R. (2013, in Indonesian). Characteristics of Litoral Sediments on Sindualang Satu Beach. Jurnal Pesisir Dan Laut Tropis, 1(1), 48-54.

Kumar, G., Ramanathan, A.L., \& Rajkumar, K. (2010). Textural Characteristics of the Surface Sediments of a Tropical Mangrove Ecosystem Gulf of Kachchh, Gujarat, India. Indian Journal of Marine Sciences, 39(3), 415-422.

Malvarez, G.C., Cooper, J.A.G., \& Jackson, D.W.T. (2001). Relationships Between WaveInduced Currents and Sediment Grain Size on a Sandy Tidal-Flat. Journal of Sedimentary Research, 71(5), 705-712. https://doi.org/ https://doi.org/10.1306/2DC40961-0E47-11D78643000102C1865D

Marfai, M.A., Tyas, D.W., Nugraha, I., 'Ulya, A.F., \& Riasasi, W. (2016). The Morphodynamics of Wulan Delta and Its Impacts on the Coastal Community in Wedung Subdistrict, Demak Regency, Indonesia. Journal of Environmental Protection, 7(1), 60-71. https://doi.org/10.4236/ jep.2016.71006

Mclaren, P., \& Bowles, D. (1985). The Effects of Sediment Transport On Grain-Size Distributions. Journal of Sedimentary Petrology, 55(4), 457-470.

Nandi, S., Ghosh, M., Kundu, A., Dutta, D., \& Baksi, M. (2016). Shoreline shifting and its prediction using remote sensing and GIS techniques: a case study of Sagar Island, West Bengal (India). Journal of 
Coastal Conservation, 20(1), 61-80. https://doi. org/10.1007/s11852-015-0418-4

Nugroho, S.H., \& Basit, A. (2014, in Indonesian). Sediment Distribution Based on Grain Size Analysis in Weda Bay, North Maluku. Jurnal IImu Dan Teknologi Kelautan Tropis, 6(1), 229-240.

Pranoto, H.R., Atmodjo, W., \& Sugianto, D.N. (2016, in Indonesian). Sedimentation Study on Groyne Building in Timbulsloko Waters, Demak Regency. Journal of Oceanography, 5(1), 86-95.

Rahmawan, G.A., Gemilang, W.A., Wisha, U.J., Dhiauddin, R., \& Ondara, K. (2019). Estimation of Sediment Distribution Based on Bathymetry Alteration (2014-2016) in the Inner Bay of Ambon, Maluku, Indonesia. Jurnal Segara, 15(2), 67-78. https://doi.org/10.15578/segara.v15i2.6956

Rahmawan, G.A., Wisha, U.J., Husrin, S., \& Ilham, I. (2017, in Indonesian). Bathymetry and Tidal Analysis at the Kampar River Estuary: "Undular Bore Bono" Tidal Wave Propagation Generator. JURNAL ILMIAH GEOMATIKA, 22(2), 57-64. https://doi.org/10.24895/jig.2016.22-2.573

Rajasekhara, D.R., Karuna, K., \& Deva, V. (2008). Textural characteristics of south western part of Mahanadi Delta, east coast of India. Jour.Ind. Assoc. Sed, 27(1), 111-121.

Rauf, A., \& Winarno, E. (2017, in Indonesian). Estimation of Limestone Resources in Pokerso Mountain, Gunungkidul Regency-DIY. Jurnal Teknologi Pertambangan, 3(1), 22-29.

Siregar, S.N., Sari, L. P., Purba, N.P., Pranowo, W.S., \& Syamsuddin, M.L. (2017, in Indonesian). Water mass exchange in the Java Sea on the periodicity of monsoons and Arlindo in 2015. Depik Jurnal, 6(1), 44-59. https://doi.org/https:// doi.org/10.13170/depik.6.1.5523

Solahuddin, T., Triarso, E., \& Troa, R.A. (2006, in Indonesian). Sediment texture characteristics based on granulometric and morphological analysis of sandstones along the Progo River in the Kalibawang-Trisik Beach, D.I.Y.. Proceddings of International Conference on Earth Science and Technology.

Sugianto, D.N., Widada, S., Wirasatriya, A., Ismanto, A., Darari, A., \& Suripin. (2017). Modelling of suspended sediment transport in coastal demak Indonesia by using currents analyzing. ARPN Journal of Engineering and Applied Sciences, 12(16), 4666-4678.
Thom, B.G., Eliot, I., Eliot, M., Harvey, N., Rissik, D., Sharples, C., ... Woodro, C. D. (2018). National sediment compartment framework for Australian coastal management. Ocean and Coastal Management, 154(January), 103-120. https://doi. org/10.1016/j.ocecoaman.2018.01.001

Tonneijck, F.H., Winterwerp, H., Weesenbeeck, B. van, Bosma, R.H., Debrot, A.O., Noor, Y.R., \& Wilms, T. (2015). Building with Nature Indonesia: securing eroding delta coastlines.

Venkatramanan, S. (2011). Grain Size Characteristics Of The Coleroon Estuary Sediments, Tamilnadu, East Coast Of India.. Carpathian Journal of Earth and Environmental Sciences, 6(2), 151-157.

Wei, B., Jiang, F., Li, X., \& Mu, S. (2009). Spatial distribution and contamination assessment of heavy metals in urban road dusts from Urumqi , NW China. Microchemical Journal, 93(2), 147152. https://doi.org/10.1016/j.microc.2009.06.001

Wentworth, C.K. (1922). A scale of grade and class terms for clastic sediments. Journal of Geology, 30(5), 377-392.

Wisha, U.J., Ondara, K., \& Kusumah, G. (2017). An Overview of Surface Water Quality Influenced by Suspended Solid Content in the Sayung Waters, Demak, Indonesia. Jurnal Segara, 13(2), 107-117. https://doi.org/https://doi.org/10.15578/ segara.v13i2.6446

Yasin, A.M., Sukiyah, E., \& Isnaniawardhani, V. (2016). Grain Size Analysis of Quartenary Sediment from Kendari Basin, Indonesia. International Journal of Science and Research (IJSR), 5(11), 1748-1751. https://doi.org/10.21275/ART20163165

Yuwono, B.D., Awaluddin, M., Kun, F.H., \& Lutfi, E.R. (2017). Evaluation of Base Station CORS UDIP and CSEM for monitoring Ground Deformation Sayung Demak Indonesia. IOP Conference Series: Earth and Environmental Science, 98(1). https://doi.org/10.1088/1755-1315/98/1/012047 